\title{
LIBRARY AS THE HEART OF A SCHOOL. THE PROJECT OF PHILLIPS EXETER ACADEMY LIBRARY, 1965-72
}

\author{
Marta Pieczara \\ Politechnika Poznańska, Wydział Architektury, Instytut Architektury i Planowania Przestrzennego \\ Poznan University of Technology, Faculty of Architecture, Institute of Architecture and Planning.
}

\begin{abstract}
Designed by the architect Louis I. Kahn, the Phillips Exeter Academy Library is renowned mostly for the quality of its inner spaces. Particularly, the image of the building's central void with its large circular openings giving an insight onto the bookshelves has almost become an archetype of the library. Following the building's design process, however, we will learn how many tangible factors participated in the actual shaping of its architecture. The uniqueness of this project relies not only on embodying the idea of the library as institution, but also on the compromises the architect took as well as on the building's adjustment to its environmental setting.
\end{abstract}

Key words: architectural design, concept, project, building's location, main entry, light, spatial hierarchy, structure, order of construction.

\section{COMMISSION}

Sent by the authorities of Phillips Exeter Academy to Louis I. Kahn's architectural office, the commission to design new buildings for the library and for a dining hall was previously elaborated in detail by the specially appointed committee. In agreement with the institution's republican tradition which lays stress on the equality of all people, and with a particular regard to its unique teaching method, called Harkness after the name of one among the school's donors and relying on the lessons being carried out in the form of discussion around an oval table, the program for the new library building precisely described the characteristics of necessary spaces. Besides the most obvious indications, like for example the number of volumes to contain or the number of reading places, it also called for delivering different types of workplaces. More precisely, the architect was required to provide both collaborative group work rooms equipped with oval tables as well as four hundred individual workplaces which could be easily adjusted so as to fit the user's personal preferences. As stated in the functional program which has been sent to the architect, "the emphasis should not be on housing books but on housing readers using books". Moreover, the authors of the functional program have commented on the ingenious use of natural light and imposed using brick on the building's exterior.

\section{PLACE}

Owing its name to the historic city of Exeter in Devon, the American town of Exeter is situated in New Hampshire, which belongs to the region known as the New England. Located nearly $20 \mathrm{~km}$ inland from the Atlantic coast, Exeter lies on the stripe of land that slopes towards the ocean and is sculpted by the network of local rivers. Due to its location in the proximity of the ocean, Exeter benefits from a milder climate than the region's interior. Despite that, however, winters are often severe in this area and abound with snowfalls, or even snowstorms, which has obvious implications on any project situated within the region.

The town's historical origins date back to the seventeenth century and are associated with the construction of a water mill. A century later, Exeter plays an important role in the history of the United States of America, becoming the scene on which the state of New Hampshire has proclaimed its independence, being the first American state to break away from the British Crown. Since then strongly associated with the republican movement, Exeter has begun to 
develop as an urban center, although it still remains a small town. ${ }^{1}$ The urban development of Exeter is from the beginning closely related to the growth of the Phillips Exeter Academy, which was established in the eighteenth century along with other city-forming institutions. During more than two centuries, the dynamic development of the Academy has led to the present situation in which the terrains owned by the school do almost fully surround the town center. [Fig. 1] The main, oldest part of the campus contains most of the Academy's historic buildings, which had different uses in the past but nowadays are prevailingly adapted to administrative and instructional functions. Over the years, the representative area of the campus, with the Academy's main building situated in its heart, played the role of a core around which further residences and sports equipments have been constructed. When in the 1960's it was decided to raise a new building for the library, the committee supervising the project on the school's behalf approved the selection of a plot located within the campus' central green space. Being close to the Academy's oldest buildings, the chosen location was intended to encourage students to visit the library at any convenient time, also between the classes. Moreover, the site hid a unique potential of opening a vast panoramic view over the central green space with its old trees. Simultaneously, the selected plot is located next to the former library, which has facilitated the collection's transfer to the new building.

These and other advantages resulting from the site's selection did nonetheless require a compromise to be made. It was namely necessary to demolish a house that formerly existed on the site and move another one, which was situated on a neighboring plot where the new dining hall was to be built. [Fig. 2]

\section{THE FIRST DESIGN PRINCIPLES}

Edited by the building committee, the new library's functional program contained a number of guidelines concerning different types of workplaces as well as creating suitable conditions so as to encourage reading. They constituted an important source of reflections for the architect who made an effort to get to know the favorite ways of students to become mired in reading and to translate them into a precise, architectural form. A bench by a window, a shared large table, soft armchairs by a fireplace or even outside benches sheltered under an arcade, which the architect got photographed during his visit in Exeter, were all integrated into the project from its conception to realization, taking part in shaping the library building.

Another vital factor which influenced the Exeter library's concept was its central location within the historic part of the Academy's campus. It was directly translated into the idea of an entry from all around. Louis I. Kahn has repeatedly emphasized his intention to shape the library's entrance in such a way that would allow a visitor upcoming from any direction to take shelter within the building as quickly as possible. Being a consequence of this concept, the idea of a portico surrounding the building in its ground floor has influenced the whole architectural composition from the project's beginning to its realization.

The following important design principle resulted from analyzing the character of local architecture as well as from indicating brick as a preferred material to be used on the building's exterior. As in the entire New England, the historic architecture of Exeter is an example of the Colonial Revival of architectural styles derived from England, and in particular of Georgian Revival. Constructed in this style, the buildings of Phillips Exeter Academy are characterized by the absolute symmetry of their plans and facades, as well as by the use of traditional masonry method. Moreover, they typically have a raised ground floor level (piano nobile) and arising therefrom outdoor stairs leading to the entrance. The main entry is generally marked with a pediment or a portico, the finesse of which testifies to the rank of the institution housed

1 About 15000 residents in 2008, according to the US Census Bureau. 
within. Cornices and opening edges are usually made of white limestone, while wooden window frames, including mullions and transoms, are painted white. Other characteristic features of the concerned architectural style are guillotine windows and expressive chimneys which mark the gable walls. [Fig. 3] In his project of the library, Louis I. Kahn decided to refer to the described architectural characteristics of the place by using traditional masonry method as well as providing a raised reference level. These two decisions, which were taken during the design's first stage, have helped to define both the quality of the spaces and the architectural character of Exeter library.

Besides many important guidelines and inspirations that were suggested by the client or resulted from the site's selection, Louis I. Kahn has thoroughly reflected on the purely philosophical sense of existence of the library as an institution. Accordingly to his own philosophical approach to architectural design, Kahn has started the work on the project by asking himself a question: "What a library should be?" It could be defined as a temple of science, the role of which is distributing knowledge. According to Kahn, however, "A man with a book goes to the light. A library begins that way." [Latour 1991 p. 76]. This definition, which refers to the reading's primary role in the process of learning and remains rooted in the Judo-Christian tradition, perceiving the book as a sacrum and as a source of enlightenment, complements the choice of a central plan. More precisely, the library building's heart is reserved for sacrum, for the unmeasurable, timeless meaning of knowledge and it remains, from the project's outset till its achievement, a symbolic void. It is surrounded by the spaces of different uses which guarantee the library's right functioning, being at the same time subordinated in relation to sacrum. Such a principle of the space organization, resulting from the architect's philosophical considerations, has overlapped with the building's central location within the Academy's campus, which has unequivocally determined the choice of central layout.

Central and strictly symmetrical, the library's plan makes reference to the archetype of a fortified castle, whose thick walls used to protect its interior and, at the same time, housed within their width a number of different-use spaces that served the main room. This archetype, studied on an example of a medieval Scottish castle, became the foundation of Louis I. Kahn's idea known as the "castle concept" [Mastelan 2000 p. 25]. It involves designing a building's layout in such a way that all servant spaces and equipments form a ring which surrounds the main, central space. Consequently, the functional connections between these spaces impose a radial type of distribution system, just as in the case of Exeter library.

Finally, one of the first concepts that have influenced the design was the architect's intention to expose the library's collection in such a way that the books would be visible straight from the threshold. While making a reference to the famous design of the Bibliothèque royale, presented in 1785 by the visionary architect Étienne-Louisa Boullée, Kahn declared that no other project has better expressed "the feeling of what a library should be - you come into a chamber and there are all the books." [McCarter 2005 p. 305] The architect has therefore decided to draw inspiration from this famous vision and to design the Exeter library's central space in such a way that would indeed reveal its collection. Kahn refers to this idea as to "the invitation of books". [Ronner 1987 p. 301]

As a result of these and other reflections, Louis I. Kahn has from the beginning imagined the library's division into three functional zones. The central void is the first of them and it gathers a symbolic dimension while giving an insight onto the bookshelves. [Fig. 7] The second, intermediate zone belongs to the books and is filled with bookshelves. Finally, the third and last one extends along the building's exterior walls and is dedicated to the reading, to the work with a book. Its peripheral location allows to fully benefit from the natural light and makes Louis I. Kahn's words "A man with a book goes to the light. A library begins that way" [Latour 1991 p. 76] take the real shape. 


\section{LOCATION AND THE CHOICE OF ENTRANCE}

In attachment to the commission, the architect has received the site's drawing on which have been marked the contours of neighboring buildings, including those to be demolished or moved, as well as the position and size of the trees growing on the plot. He has also received the facade drawings of the school's main building (Academy Building), of the old library (Davis Library), which is situated right next to the selected site, as well as of the Dunbar Hall, which is one of the students' residences that form the west frontage to the central green space of the Academy's campus. Built during the first decades of the twentieth century, all of the three mentioned buildings had been designed by the architects Cram and Ferguson in the Georgian Revival style. Being in possession of such extended documentation, Louis I. Kahn took his first decisions concerning the library's situation on the site. Out of the available land he selected a place that was previously occupied by the house being demolished, saving most of the nearby trees. Referring to the main axis of the Academy's campus, which is also the axis of symmetry of its main building, the architect did at the same time determine the new trend of shaping the east frontage of the central green space. Another key decision that Louis I. Kahn took at that moment was adjusting the new library's reference level to that of the old one, what was marked in red on the Davis Library facade's drawing that the architect owned. Conscious of a great scale difference between the new and the old buildings, Kahn has furthermore decided to offset the designed new library in depth of the central green space, so as not to align with much smaller Davis Library.

Along with the choice of situation on the site the architect has made a decision concerning the location of the building's main entrance. The portico mentioned above, which surrounds the library on the ground level so as to give effect of entering from any direction, leads around the building to its main entry. From the project's first draft, it is invariably located in the library's north facade, facing the Academy's main building. [Fig. 2]

\section{DESIGN STAGES AND IMPLEMENTATION}

The development of the Exeter library's project can be divided into three essential stages, the common denominator of which was the need of cutting costs and the resulting usable space reduction. Simultaneously, each phase has brought the architect's responses to various problems he encountered.

The project's first version, presented in May 1966, can be summarized as formalization of the design's first principles in the form of a conceptual solid, subsequently embedded in the reality of the selected plot. In this version, the building of the library was based on a square plan, the corners of which were emphasized by four massive towers. Among them, the two flanking the north facade were larger, most likely to accentuate the main entrance's situation in between. Related to this version, the building's section drawing showed its layout over eight floors, two of which were mezzanines. Furthermore, a basement was located under a part of the building's plan, while its highest storey was almost entirely occupied by a terrace. Simultaneously, the library's main level was its first floor, which is an undoubted reference to the piano nobile of the Italian Renaissance palaces. Additionally, the concerned version of the library's design was characterized by a ceremonial nature of the distribution spaces as well as by the traditional way of laying bricks. Having approved the overall concept, the client has nonetheless suggested a few modifications. Presented again in the autumn of 1966, the same version of the project had already two towers instead of four, while the building's highest floor was in the larger part occupied by additional rooms for team working as well as for storing rare books. The central void was given a pyramidal roof while its walls were made independent from the slabs and gave an insight onto the bookshelves through enormous circular openings. Moreover, the architect had until then elaborated his design of a workplace mounted on the 
outer walls and equipped with sliding shutters, allowing the user to adjust the quantity of light falling on his desk so as to fit his personal preference. Visible from the outside, the differently positioned shutters do also make the facade alive and more welcoming.

Despite its overall acceptance, the first version of the library was nevertheless criticized for its high cost as well as for its maladjustment to the region's climate conditions. Trying to respond to these complaints, Louis I. Kahn promised to revise the project. In the first place, he reduced the building's surface, replaced some of the used brick with concrete and minimized the use of other expensive materials. Besides, the architect gave up the idea of both the roof terrace and the towers containing outdoor stairs. Instead, he redefined the inner communication, service and sanitary ducts, shaping them into the form of corner towers. Kahn also proposed to bevel the building's corners, most probably with an intention to visually reduce its width. During the second phase of the design the architect has also dealt with a very difficult task of adapting the building's scale to the environment. At the time, Exeter authorities implemented the new town zoning code banning buildings over three stories [Brownlee 1991 p.392]. Even though the client has successfully obtained an exemption from that requirement, Louis I. Kahn had already taken, on his own initiative, the effort to fit his project of a nine-level library into its historical context, despite a significant height difference when compared to the local threeto four-storey building standard. To be more specific, the architect has tried to hide the real number of floors behind the facade with two-storey height openings, whose proportions were derived from the local architectural models (Fig. 5). In consequence, a half of the library's floors are mezzanines. Owing to such solution, the nine-level interior of the library is hidden under the formal appearances of a four-storey building.

The third and final project stage was marked by further cost cutting and the resulting compromises. The architect tried though to resign only from these elements whose lack would not affect the already established building's character. First of all, he decided to reject the idea of a paved plaza in front of the entrance as well as all groundworks resulting from the site plan. He also resigned from the stone lintels. However, Louis I. Kahn has strongly refused to the client's suggestion to remove the first mezzanine, which would negatively affect carefully polished facade proportions. In order to save the mezzanine, the architect suggested to reduce his own fees [Wickersham 1988 p.143/144]. During the design's final stage Kahn has also modified the central void's roofing, which is since then covered with a slab, carried by the two double storey high beams crossed in the center. [Fig. 9] This modification has also resulted in the diagonal arrangement of the pillars supporting the central space's walls and roofing. Last but not least, the architect has refined the form of the entrance lobby, which now overruns a portion of the peripheral portico's surface, becoming more spacious and comfortable. [Fig. 4]

\section{LIGHT}

According to the architect's device, the quality of natural light defines the character of differently used spaces. In case of the Exeter library two essential types of daylight can be distinguished. First one is strictly related to the functionality of the peripheral spaces, adjacent to the building's outer walls and containing individual workplaces. Most suitable for reading, white daylight penetrates into the interior through large windows. In the workplaces situated directly under the windows the light's intensity can be controlled by means of sliding shutters. [Fig. 8] Further in the library's depth where the mezzanines are situated, however, light coming through the windows has already been diffused by the building's structure and does not require any monitoring tools to be installed. The other kind of natural light, entirely different from the previous one, comes from the narrow window slits situated just below the ceiling of the central, multi-storey space. [Fig. 9] This sort of light, slightly blue and deprived of the glaring capacity, is restricted to be used in the central void only and it emphasizes its symbolic character. 


\section{STRUCTURE AND THE ORDER OF CONSTRUCTION}

The library's structure consists of a poured concrete central core and the surrounding brick periphery. The duality of used materials has helped the architect to express the intentionally differentiated nature of the two structures. Louis I. Kahn calls them "doughnuts" [Ronner 1987 p.301] and explains their different purposes. Specifically, the concrete core is designed to protect the books from light, while the outer "doughnut" is meant to stay independent from books. Moreover, it ought to be mentioned that the outer, brick envelope plays an important role when it comes to referring to the context, successfully blending into the local architecture.

Resulting from the use of two different materials, the order of construction is diverse for the concrete interior and for the brick exterior. For fear of cracking at the junction of the two structures, it was decided to accomplish the monolithic inner structure at first. Only after its completion the surrounding brick periphery was realized. Determining its first impression, the building's facades are built of "Eno" brick, manufactured at the local brickyard. It is precisely the same sort of brick of which the Academy's historical buildings were raised. Furthermore, the architect has decided to apply the traditional method of laying bricks, using also brick lintels as well as reducing the cross section of the pillars between openings with each successive row of windows.

\section{SUMMARY}

Louis I. Kahn, who had "never lost his love of the old buildings" [Wiggings 1997 p.12], as he said himself, has used the contextual analysis as a foundation to develop some of the design tools which reliably helped him to realize projects that were modern and, at the same time, related to their surroundings. One of these tools is facade, independent of the building's inner structure and being adjusted to its contextual frame. Precisely refined during the Exeter library project, starting from the openings' proportions and ending at masonry method, Louis I. Kahn's facade speaks the same language as its historical neighbors do, without being alien to the functionality housed inside. On the contrary, the building's function plays an important role in transferring the ideological principles of the architectural concept.

\section{BIBLIOGRAPHY}

Bibliothèques, 1993/94. EPFL-DA-Atelier de 2ème année, Cahier Nº4, Lausanne.

Brownlee D., De Long D., 1991. Louis I. Kahn. In the Realm of Architecture, Rizzoli, New York. p. 392

GA (Global Architecture)., 1975. Louis I. Kahn. Indian Institute of Management, Ahmedabad, India, 1963, Exeter Library, Phillips Exeter Academy, Exeter, New Hampshire, USA, 1972, ADA Edita, Tokyo.

Latour A., 1991. Louis I. Kahn: Writings, Lectures, Interviews, Rizzoli, New York. p. 76

Mastelan P. [red.], 2000. Louis I. Kahn. Silence and Light. Actualité d'une pensée, Cahiers de théorie 2/3, Presses polytechniques et universitaires romandes, Lausanne. p. 25

McCarter R., 2005. Louis I. Kahn, Phaidon, London. p. 305

Ronner H., Jhaveri Sh., 1987. Louis I. Kahn. Complete Work 1935-74, Second Revised and Enlarged Edition, Birkhäuser, Basel Boston. p. 301

Trentin A., 2010. Louis I. Kahn, tł. Piot Ch., Actes Sud, Arles.

Wickersham J., 1988. The Making of Exeter Library, The Harvard Architecture Review nr 7. p. 143/144

Wiggins G.E., 1997. Louis I. Kahn. The Library at Phillips Exeter Academy, Van Nostrand Reinhold, New York. p. 12

Wurman R.S. [red.], 1986. What Will Be Has Always Been: The Words of Louis I. Kahn, Access Press i Rizzoli, New York. 


\section{ILLUSTRATIONS}

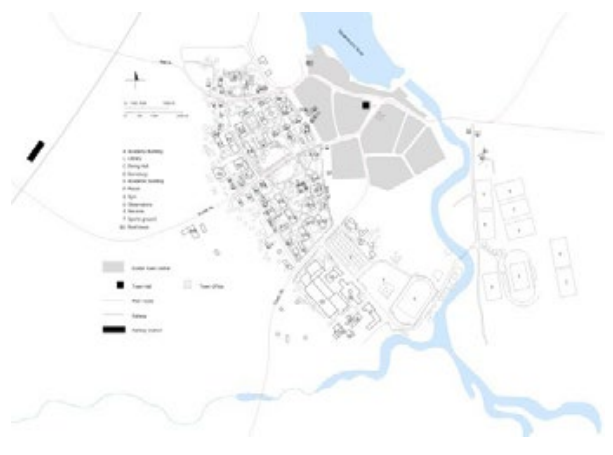

Fig. 1. Campus of the Phillips Exeter Academy Ryc. 1. Kampus Akademii Philips Exeter,

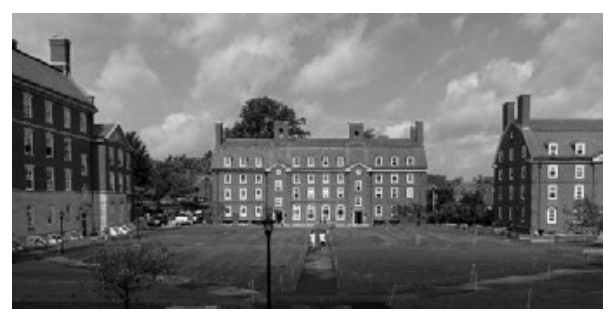

Fig. 3. Typical buildings of the Academy. The Georgian Revival style.

Ryc. 3. Typowy przykład budynku Akademii,
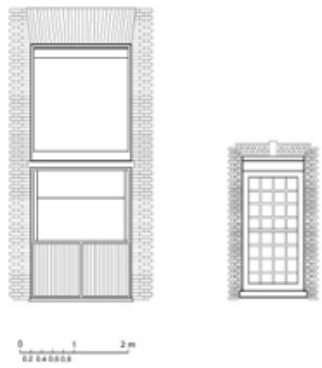

Fig. 5. Windows from the piano nobile of the library (left) and the Academy's main building (Acadamy Building, right). Ryc. 5. Okna piano nobile biblioteki (lewy) oraz głównego budynku Akademii (prawy)

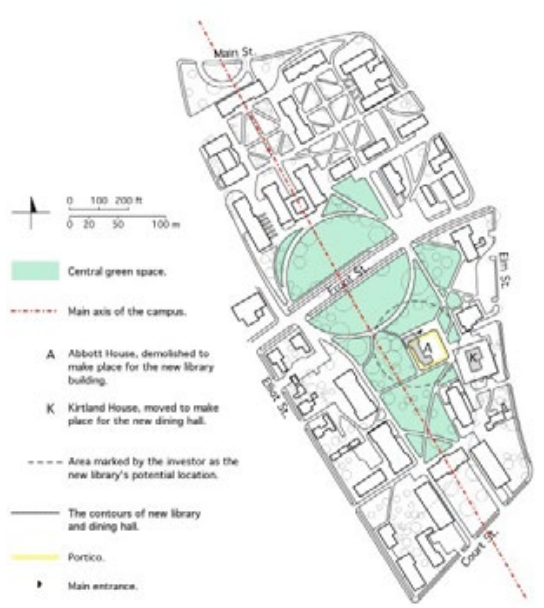

Fig. 2. The library's situation Ryc. 2. Usytuowanie biblioteki,

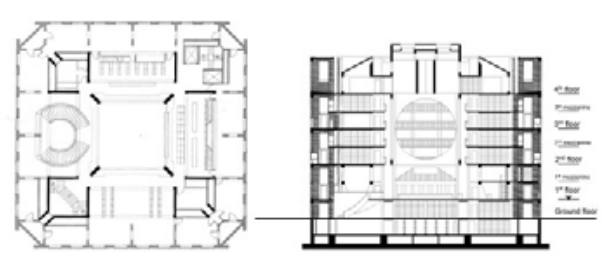

Fig. 4. The library design's final version, November, 1968. A plan of the first floor (piano nobile) and a section.

Ryc. 4. Rzut parteru oraz przekrój ostatecznej wersji projektu biblioteki.

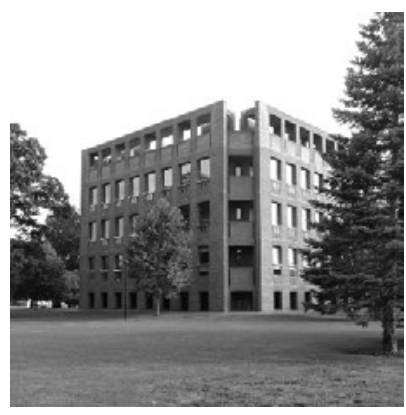

Fig. 6. View of the library, 2010. Ryc. 6. Biblioteka, 2010. 


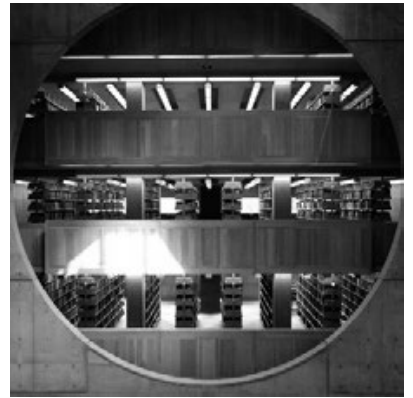

Fig. 7. "Invitation of books". An opening in the central void's wall, giving an insight onto the bookshelves, 2010.

Ryc. 7. Otwarcie widokowe jako otwór w ścianie umożliwiający widok regałów z książkami.

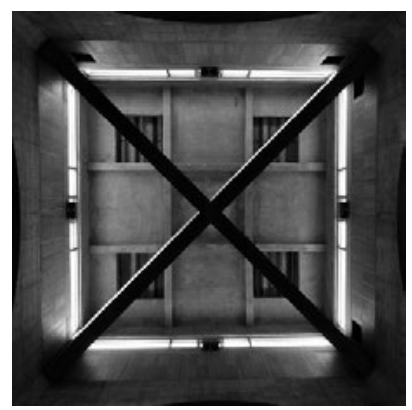

Fig. 9. The central void's roofing, 2010. Ryc. 9. Widok centralnej części dachu, 2010.

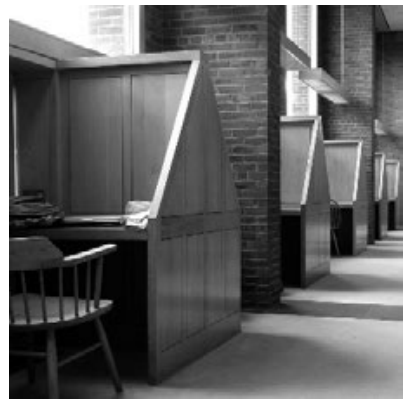

Fig. 8. Individual workplaces, 2010. Ryc. 8. Indywidualne miejsca do pracy.

\section{BIBLIOTEKA SERCEM UCZELNI. PROJEKT BIBLIOTEKI PHILLIPS EXETER ACADEMY, 1965-72.}

Streszczenie. Zaprojektowany przez architekta Louisa I. Kahna, budynek biblioteki Phillips Exeter Academy słynie głównie z jakości zawartych w jego wnętrzu przestrzeni. Zwłaszcza obraz jego centralnej pustki, z jej potężnymi, okrągłymi otworami dającymi wgląd na regały książek, stał się już niemal archetypem biblioteki. Śledząc proces twórczy, jednakże, dowiemy się, jak wiele namacalnych czynników zewnętrznych wzięło udział w rzeczywistym kształtowaniu architektury tego budynku. Niepowtarzalność tego projektu polega nie tylko na ucieleśnieniu idei biblioteki jako instytucji, ale również na powziętych przez architekta kompromisach oraz na dostosowaniu się do otoczenia.

Słowa kluczowe: projektowanie architektury, koncepcja, projekt, usytuowanie budynku, wybór wejścia, światło, hierarchia przestrzeni, struktura, porządek konstrukcji. 